\title{
Harmonizing the Assessment of the Impacts of Natural Disasters to Florida Agriculture ${ }^{1}$
}

\author{
Christa Court, Alan Hodges, and Matt Lollar ${ }^{2}$
}

\section{Introduction}

Since 1980, the state of Florida has experienced 56 major natural disasters, including hurricanes and tropical storms, wildfires, droughts, flooding, freezes, and other severe weather events. These disasters are associated with a total of $\$ 5$ to $\$ 10$ billion in economic losses for the state of Florida each year (NOAA NCEI 2019). Not surprisingly, natural disasters can cause a variety of damages that result in economic losses to many segments of production agriculture and cause disruptions in other related economic sectors that supply agricultural inputs and services. Agricultural production losses might include crops, livestock, and animal products. Assets at risk of damage include farm homes, buildings, machinery/equipment, fencing, irrigation systems, other infrastructure, and perennial plantings such as standing timber, fruit orchards, and vineyards. Agricultural producers may also incur increased costs for additional production inputs that have to be reapplied, as well as cleanup and repairs, and might face temporary loss of farm labor or long-term loss of market share to competing producers in other regions. Depending on the size and scope of the disaster, agricultural business owners and employees could suffer reduced earnings that can lead to household financial insecurity and social stress, and consumers could experience temporary food insecurity.
Timely provision of credible estimates of the agricultural losses associated with natural disasters is a critical component in the processes of official disaster declaration and disaster relief and recovery. Florida's Cooperative Extension system is recognized as a reliable and unbiased source for this information. However, the manner in which data on agricultural losses and damages has been collected, analyzed, and published presents challenges for the multiple stakeholders involved in the process, including faculty, state and federal agencies, and industry groups. An online survey instrument was designed to harmonize the data collection process for Florida's Cooperative Extension system. This document describes the survey instrument and communicates how the data are used in analyses of economic losses.

\section{Current Challenges}

There are several challenges for both University of Florida Institute of Food and Agricultural Sciences (UF/IFAS) Extension agents collecting information in the field and for UF/IFAS Extension faculty using these data to determine the overall economic impacts associated with a natural disaster event. One challenge is that there are redundant and sometimes uncoordinated efforts. In the past, UF/IFAS Extension agents in Florida were asked to complete multiple reports associated with agricultural damages and losses for university administration as well as county- and state-level agencies using several different forms and formats, which led to confusion. This causes

1. This document is FE1075, one of a series of the Food and Resource Economics Department, UF/IFAS Extension. Original publication date March 2020. Visit the EDIS website at https://edis.ifas.ufl.edu for the currently supported version of this publication.

2. Christa Court, assistant scientist, Food and Resource Economics Department and assistant director, Economic Impact Analysis Program; Alan Hodges, Extension scientist emeritus, Food and Resource Economics Department; and Matt Lollar, UF/IFAS Extension horticulture agent, UF/IFAS Extension Jackson County; UF/IFAS Extension, Gainesville, FL 32611.

The Institute of Food and Agricultural Sciences (IFAS) is an Equal Opportunity Institution authorized to provide research, educational information and other services

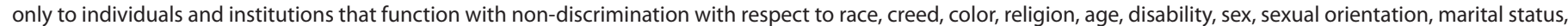

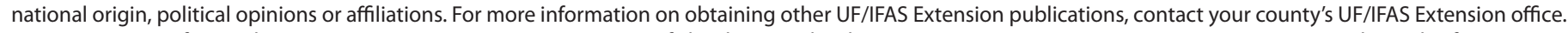
U.S. Department of Agriculture, UF/IFAS Extension Service, University of Florida, IFAS, Florida A \& M University Cooperative Extension Program, and Boards of County Commissioners Cooperating. Nick T. Place, dean for UF/IFAS Extension. 
UF/IFAS Extension agents and faculty to waste precious time and could detract from the vital mission to assist in disaster recovery or result in inconsistent information. Timely provision of credible estimates of the agricultural losses associated with natural disasters is also paramount to the political processes associated with state- and federal-level natural disaster relief. Another challenge is the confusion regarding the distinction between "losses" and "damages." Losses generally represent a decrease in annual revenue flows for agricultural products and services due to reduced production levels, i.e., farm gate sales, or increased production costs. Damages, on the other hand, represent destruction of capital assets that must be replaced or repaired, or that have reduced capacity. Information on these impacts must be collected and evaluated separately. There is also a challenge related to the timing of losses. Some losses are immediate, while others might manifest over weeks, months, or even years. For example, flooding of citrus groves could potentially result in reduced yields or increased susceptibility to pests and disease in future years. Finally, the complexity of Florida agriculture makes it challenging to evaluate comprehensively the economic impacts of disasters. Unlike many other states that have only a few major commercial agricultural commodities, Florida produces nearly 300 different agricultural commodities, and the mix of these commodities varies widely across the state and by season.

\section{Harmonizing Disaster Data Collection: Overview of Online Survey Instrument}

To address some of the challenges noted above, an online survey instrument was developed by UF/IFAS Extension to assist Florida's Cooperative Extension system in collecting disaster impact information using the Qualtrics ${ }^{\circledR}$ survey system, which is the standard survey platform licensed by the University of Florida, recognized for its robust data security, analytics, and logical control programming features. The online survey instrument allows for more timely and accurate reports on observed damages.

The survey was designed to collect information in a format that is compatible with the requirements of the United States Department of Agriculture (USDA) Farm Service Agency for disaster reporting and official disaster declaration (USDA 2012) as well as the requirements of the Florida Department of Agriculture and Consumer Services. With its comprehensive nature and the ability to generate multiple types of reports for different agencies, this survey tool is designed to eventually replace all previous reports filled out by Florida's Extension agents.

In the event of a natural disaster, the UF/IFAS Extension Administration team will distribute an invitation to participate in the survey, along with a link to the online survey. The survey is compatible with both desktop computers and mobile devices with either Android or iPhone operating systems. In the event that internet service is not available, an offline version of the survey can be used by registered Qualtrics ${ }^{\circledR}$ users, or a paper copy of the survey can be filled out (see Appendix B).

The survey should be completed for each agricultural operation observed or farm owner/manager interviewed. Respondents should complete the survey as many times as possible to get a representative sample of operations affected by the disaster in their county or multi-county area, of course subject to time constraints and safety concerns for possibly hazardous field conditions after a disaster. It is up to the knowledge and experience of the local Extension agent to determine what different types of agricultural commodities should be surveyed in his/her area. The survey is voluntary, and there is no compensation provided for completing the survey.

A test version of the survey can be found at Disaster $\mathrm{Ag}$ Loss and Damage Survey. The paper version of the survey can be found in Appendix B.

The disaster assessment survey requests information including the name of the respondent and farm or farm owner, the county or counties in which the business is located, the type of disaster, and whether the record is a first-hand, in-person observation or second-hand information from a farm owner/manager or other person with knowledge of the situation. The types of disasters for which the survey instrument is employed might include hurricane/tropical storms, severe weather, tornados, extreme wind, excess rain, floods, droughts, hail events, freeze, excess heat, wildfires, or other extreme weather events.

The survey first asks respondents to indicate the broad categories of agricultural commodities affected by the disaster:

- Field crops

- Horticultural crops-greenhouse and nursery

- Vegetables, melons, and potatoes

- Fruits and nuts

- Livestock and animal products 
For each category of commodity selected, respondents are asked to indicate the specific commodities affected, as shown in Table 1, listed in alphabetical order. For each of the crops selected, the survey solicits information on the total farm area planted in the crop, the area destroyed by the disaster (100\% loss), and the area partially destroyed (less than 100\% loss). The area would be entered as acres for all field crops, vegetables/melons/potatoes, and fruits/nuts, or as square feet for ornamental greenhouse and nursery crops. Information is also entered for each selected crop on the anticipated damaged yield (units per acre or units per square foot) and the normal yield for the farm or percent of normal yield. Units for each crop might be in terms of tons, pounds, bushels, or number of plants, as appropriate. For livestock, the survey asks for information on the number of animals on the farm, and the number that were lost (or died) as a result of the disaster. For beef and dairy cattle, the animal numbers are requested separately for animals greater than or less than 400 pounds. For animal products such as milk, eggs, and honey, information would be input on the production level for last year, and the volume of product destroyed by the disaster incident.

After completing information on agricultural commodities, the survey asks for information on damages for the following types of infrastructure and fixed assets:

- Homes and farm buildings

- Greenhouses and growing structures

- Irrigation equipment

- Farm equipment

- Fences

- Conservation structures

- Perennial plants, e.g., fruit/nut orchards, vineyards (number plants/trees)

- Other (specify)

An example of the survey data-entry process is provided in Appendix A.

\section{What happens to the data?}

The information entered in the survey will be downloaded by investigators from the Economic Impact Analysis Program, which resides within the UF/IFAS Food and Resource Economics Department, for compilation and analysis of results. All data for individual farm businesses and survey respondents will be maintained confidentially, and only group totals or averages will be disclosed, as per the terms of the University of Florida Institutional Review Board (UF IRB) approval for this survey.

The investigators will compile the survey information for all commodities in each county affected by the disaster and summarize in terms of total area destroyed, area partially destroyed, damaged yield, and percentage of commodity lost. The survey information will then be used to calculate average levels of percentage losses to estimate the share of total volume and value of each commodity lost based on available baseline information for the most recent year on total area, volume, price, and value of commodities in each county from sources such as the US Census of Agriculture and annual surveys by the USDA National Agricultural Statistics Service and the Florida Department of Agriculture and Consumer Services.

A summary of the estimated commodity losses and asset damages will be available on the Economic Impact Analysis Program's Disaster Impact Analysis website (https://fred. ifas.ufl.edu/economicimpactanalysis/Disasterimpactanalysis/) and will be provided to members of the Florida Cooperative Extension system, the Florida Department of Agriculture and Consumer Services, and the USDA Farm Service Agency Florida headquarters for consideration in official disaster declaration and in support of disaster relief and recovery efforts. Under USDA rules, there must be at least a 30 percent loss of one agricultural commodity in a county in order to be eligible for a disaster declaration.

\section{References}

USDA Farm Service Agency (FSA). 2012. FSA HandbookDisaster Designations. https://www.fsa.usda.gov/Internet/ FSA_File/1-dis_r00_a01.pdf

NOAA National Centers for Environmental Information (NCEI). 2018. U.S. Billion-Dollar Weather and Climate Disasters. https://www.ncdc.noaa.gov/billions/ 
Table 1. List of specific agricultural commodities covered in the disaster impact survey.

\begin{tabular}{|c|c|c|c|c|}
\hline Fruits and Nuts & $\begin{array}{c}\text { Vegetables, Melons, } \\
\text { Potatoes }\end{array}$ & Field Crops & $\begin{array}{c}\text { Greenhouse and } \\
\text { Nursery }\end{array}$ & Livestock/Animal Products \\
\hline Apples & Asparagus & Canola & Aquatic Plants & Alpacas \\
\hline Apricots & Beans & Corn & $\begin{array}{l}\text { Bulbs, Corms, Rhizomes } \\
\text { \&Tubers }\end{array}$ & Bison \\
\hline Avocados & Beets & Cotton & Christmas Trees & Cattle, Beef \\
\hline Bananas & Broccoli & Grasses \& Legumes & $\begin{array}{l}\text { Cut Flowers \& Cut } \\
\text { Cultivated Greens }\end{array}$ & Cattle, Dairy \\
\hline Blackberries & Cabbage & Hay, Haylage, Silage & Floriculture, Other & Chickens \\
\hline Blueberries & Carrots & Millet & $\begin{array}{l}\text { Flower or Vegetable } \\
\text { Seeds }\end{array}$ & Deer \\
\hline Berries, Other & Cauliflower & Oats & Flowering Plants, Potted & Ducks \\
\hline Cherries & Celery & Peanut & Tropical Foliage Plants & Eggs \\
\hline Chestnuts & Cantaloupe & Peas & Mushrooms & Elk \\
\hline Citrus, Other & Cucumbers & Popcorn & Propagative Material & Emus \\
\hline Figs & Daikon & Rice & Transplants & Equine (Horses, Donkeys) \\
\hline Grapes & Eggplant & Rye & $\begin{array}{l}\text { Woody Ornamental Trees } \\
\text { and Shrubs }\end{array}$ & Finfish \\
\hline Guava & Escarole \& Endive & Sesame & & Goats \\
\hline Kumquats & Garlic & $\begin{array}{l}\text { Short-Term Woody } \\
\text { Crops }\end{array}$ & & Guineafowl \\
\hline Lemons & Greens & Sod & & Hogs \\
\hline Limes & Herbs & Sorghum (Grain) & & Honeybee Colonies \\
\hline Loganberries & Lettuce & Soybeans & & Honey \\
\hline Mangoes & Melons, Other & Sugarcane & & Milk \\
\hline Nectarines & Onions & Sunflower & & Ostriches \\
\hline Non-citrus Fruits, Other & Parsley & Tobacco & & Pheasants \\
\hline Olives & Peas & Triticale & & Pigeons \& Squab \\
\hline Oranges & Peppers & Wheat & & Poultry, Other \\
\hline Papayas & Potatoes, white & Other Field Crops & & Quail \\
\hline Passion Fruit & Pumpkins & & & Rabbits \\
\hline Peaches & Radishes & & & Sheep \\
\hline Pears & Spinach & & & Shellfish \\
\hline Pecans & Squash & & & Specialty Animals, Other \\
\hline Persimmons & Sweet Corn & & & Turkeys \\
\hline Plums \& Prunes & Sweet Potatoes & & & \\
\hline Pomegranates & Tomatoes & & & \\
\hline Strawberries & Vegetables, Other & & & \\
\hline Tangelos & Watercress & & & \\
\hline Tangerines & Watermelon & & & \\
\hline \multicolumn{5}{|l|}{ Temples } \\
\hline Tree Nuts, Other & & & & \\
\hline
\end{tabular}




\section{Appendix A: Example Disaster Scenario and Survey Responses}

An example disaster scenario was developed to demonstrate use of the online survey instrument. In this scenario, it is assumed that a Category 2 hurricane makes landfall in Collier County, impacting commercial orange grove operations. Our fictional UF/IFAS Extension Collier County agent, John Doe, receives an invitation to participate in the survey from UF/IFAS Extension Administration, which includes a link to the online survey instrument. Once mobilized, the UF/IFAS Extension agent observes the damages to a local orange grove operation owned by Jane Smith by driving around the perimeter of the operation, which encompasses 1,000 acres of land. The agent observes that approximately $30 \%$ of the fruit has fallen from the trees and that roughly 200 trees have fallen over. There is also one farm building damaged that is visible from the road. After pulling off the road to record the observations, the agent accesses the online survey instrument via a laptop computer or handheld device with mobile data capabilities. In the event that internet service is not available, an offline version of the survey can be used by registered Qualtrics ${ }^{\circledR}$ users, or a paper copy of the survey can be filled out (see Appendix B). Figure 1 shows the initial display encountered on the survey, which is an invitation to participate in the post-disaster survey of agricultural damages and losses.

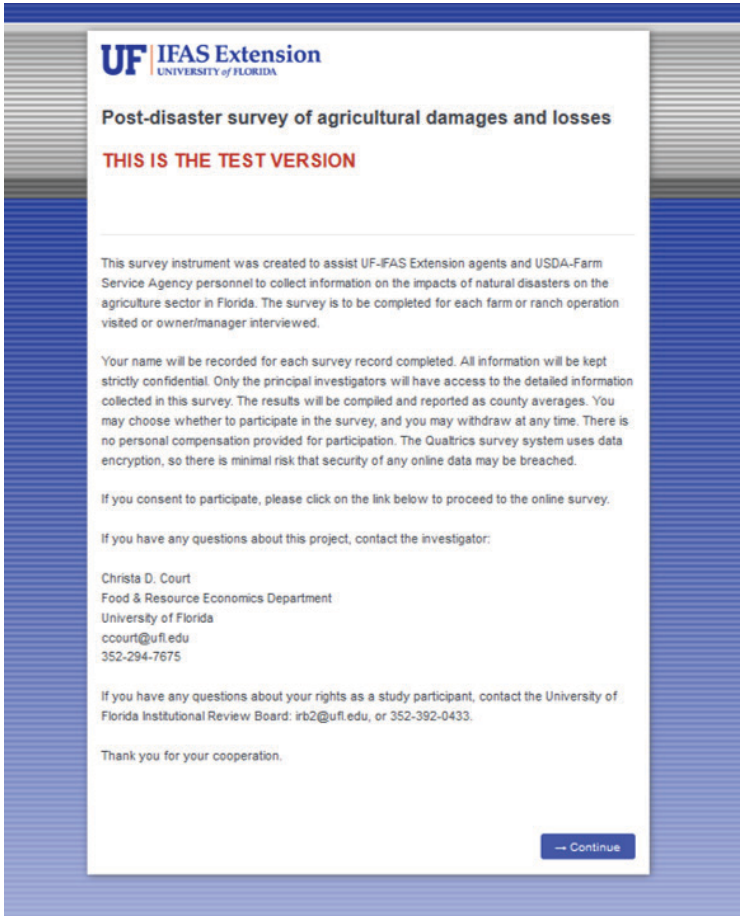

Figure 1. Invitation to participate in the post-disaster survey of agricultural damages and losses.
The respondent consents to participate by clicking on the blue Continue button in the bottom right corner of the display and will proceed to the survey ${ }^{1}$. On the next screen, the agent will be prompted to enter their name (Observer name), the type of observation that they are reporting (i.e., whether it was a first hand observation or second hand observation), and the name of the farm or the owner of the farm that they are observing. In this case, the agent would enter their name (John Doe), select the radio button for First-hand: In-person observation, enter the name of the commercial citrus grove or its owner (Jane Smith), and press Continue, as shown in Figure 2.

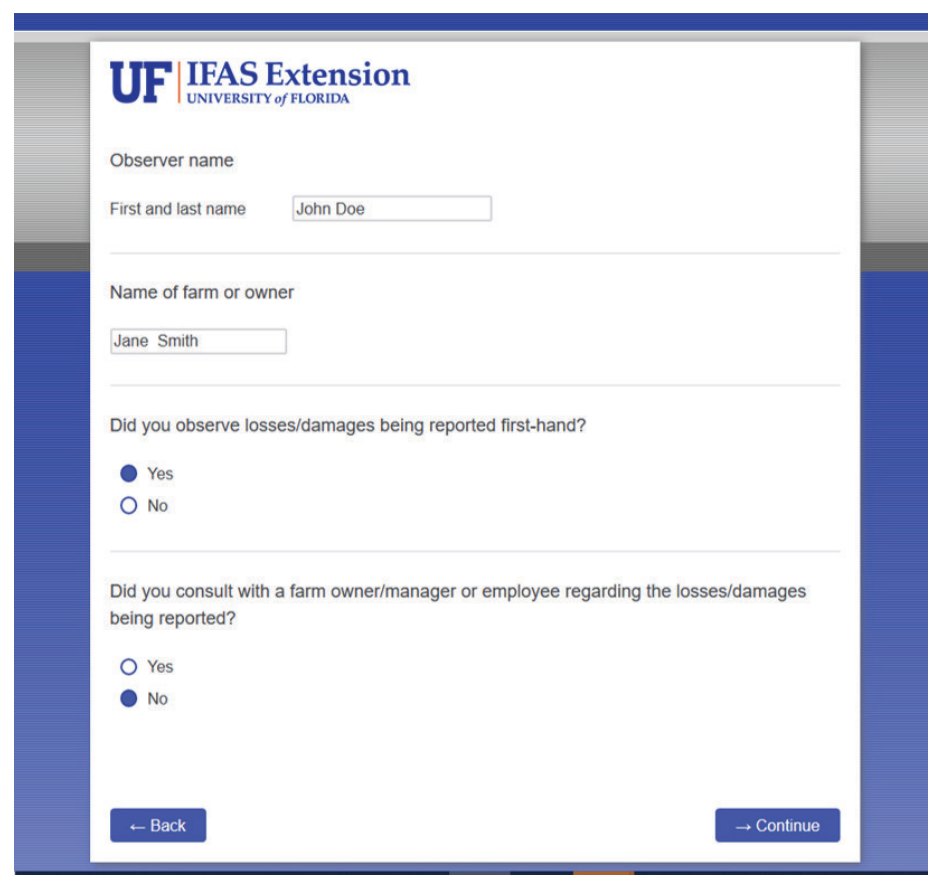

Figure 2. Entering details about the observer and property observed.

On the next screen, the survey respondent is prompted to select the county within which the property being observed is located. If the operation crosses county boundaries, the respondent can make multiple selections. For this scenario, the agent would select the check box for Collier county and press Continue, as shown in Figure 3 (the respondent must scroll down to view all counties and the Continue button).

The next two screens prompt the survey respondent for information on the type of disaster that occurred and the agricultural commodity groups affected by the disaster. If applicable, the survey respondent can select multiple agricultural commodity groups affected. In this example, the Extension agent would select the check boxes for Hurricane/Tropical Storm and Fruits and Nuts, as shown in Figures 4 and 5. 


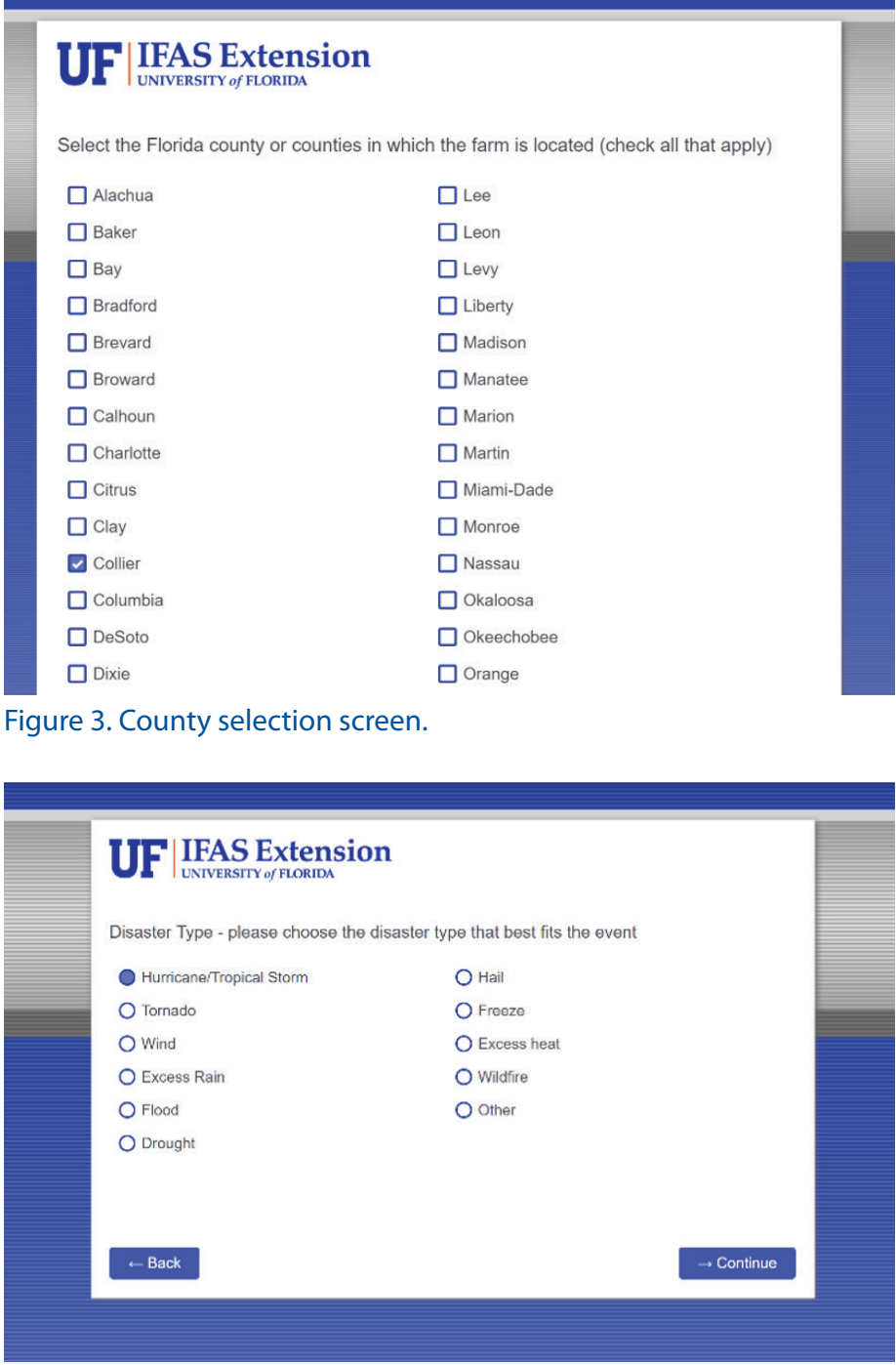

Figure 4. Entering information on disaster type.

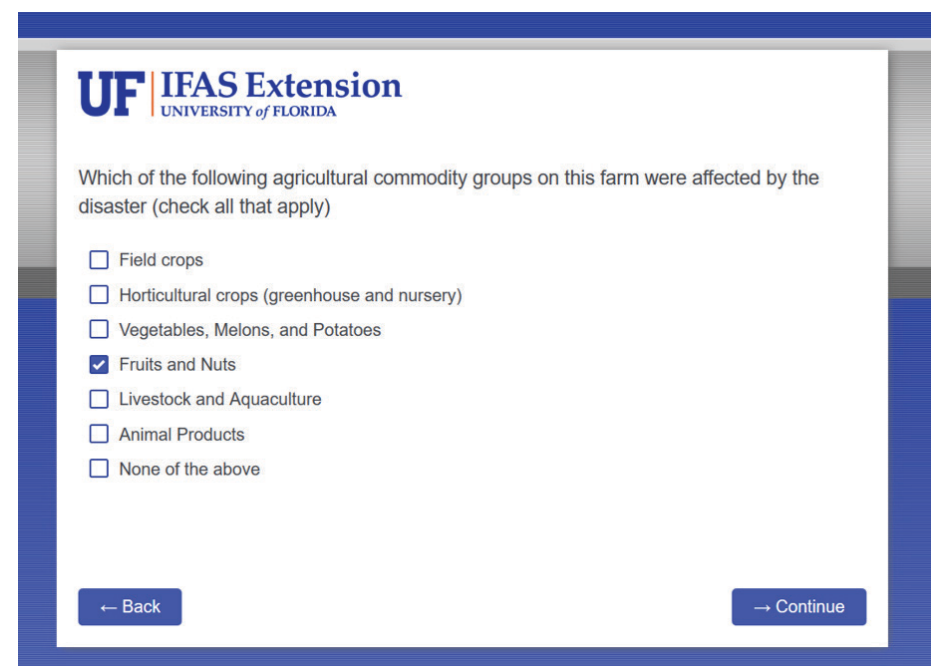

Figure 5. Entering information on agricultural commodity group affected.
From this point on in the survey, the questions displayed will depend on the selections that have been made with respect to the agricultural commodity group affected. For this example, only the screens and survey questions relevant to the example are displayed. The next screen that the agent will see for this example prompts the agent for information on the specific agricultural commodity affected within the Fruits and Nuts group that was selected on the previous screen. In this case, the agent will select the radio button for Oranges and press Continue, as shown in Figure 6.

\begin{tabular}{|c|c|}
\hline \multicolumn{2}{|c|}{ UF $\mid$ IFASIVRSITY Exten FLRIDA } \\
\hline \multicolumn{2}{|c|}{ Select the fruit or nut crops that were affected (check all that apply) } \\
\hline$\square$ Apples & $\square$ Lychee \\
\hline Apricots & $\square$ Mamey \\
\hline Avocados & $\square$ Mangoes \\
\hline$\square$ Bananas & $\square$ Nectarines \\
\hline$\square$ Blackberries & $\square$ Non-Citrus fruits, other \\
\hline$\square$ Blueberries & $\square$ Olives \\
\hline$\square$ Berries, other & ■ Oranges \\
\hline$\square$ Cherries & $\square$ Papayas \\
\hline$\square$ Citrus, other & $\square$ Passion Fruit \\
\hline$\square$ Chestruts & $\square$ Peaches \\
\hline Dragon fruit (Pitaya) & $\square$ Pears \\
\hline$\square$ Figs & $\square$ Pecans \\
\hline$\square$ Grapefruit & $\square$ Persimmons \\
\hline$\square$ Grapes & $\square$ Plums \\
\hline$\square$ Guavas & $\square$ Sapodilla \\
\hline$\square$ Kumquats & $\square$ Pomegranates \\
\hline QLemons & $\square$ Tangelos \\
\hline$\square$ Limes & $\square$ Tangerines \\
\hline$\square$ Loganberries & $\square$ Temples \\
\hline$\square$ Longan & \\
\hline
\end{tabular}

Figure 6. Specific agricultural commodity selection screen (specific to this example).

The next screen provides additional information on how to answer and how to input answers for the next set of questions within the survey on area and yield. This informational screen is shown in Figure 7.

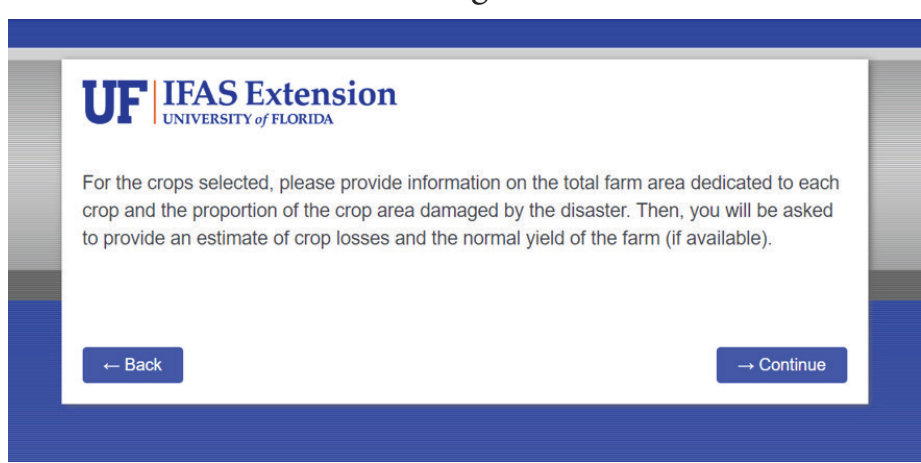

Figure 7. Information on entering observations on area and yield affected.

On the next screens, the respondent will enter information on the total farm area, the proportion of total crop area damaged by the disaster, the proportion of total crop 
production lost to the disaster, the totally destroyed area, and the normal yield for the observed citrus grove. For oranges, this information is entered in acres (area) and boxes per acre (yield). Recall that the destroyed area indicates acres that are considered a $100 \%$ loss due to the disaster, and the damaged acres represent the area that was partially destroyed (less than 100\% loss) during the disaster. Potential observed estimates pertaining to area and yield for this example are shown in Figures 8-12.

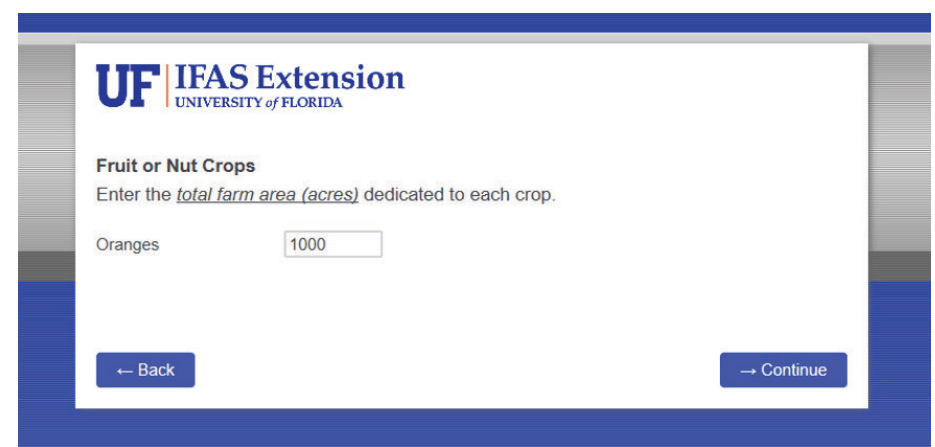

Figure 8. Entering information on total farm area.

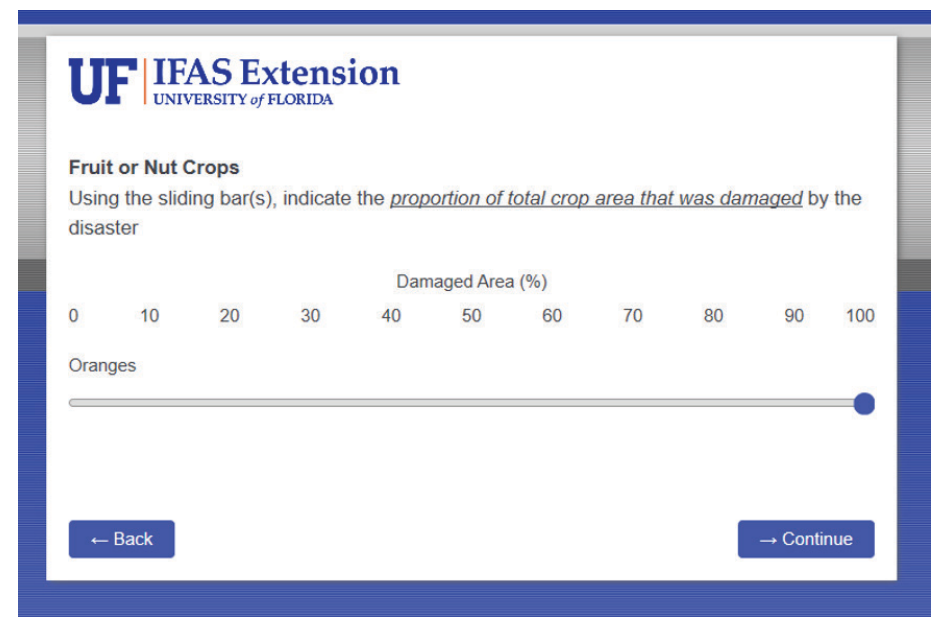

Figure 9. Entering information on proportion of crop area that was damaged.

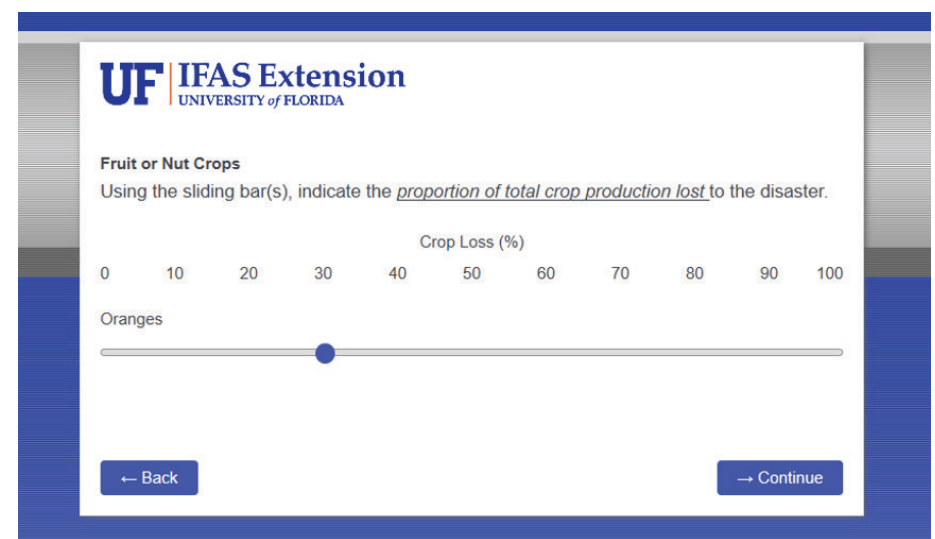

Figure 10. Entering information on the proportion of total crop production lost to the disaster.

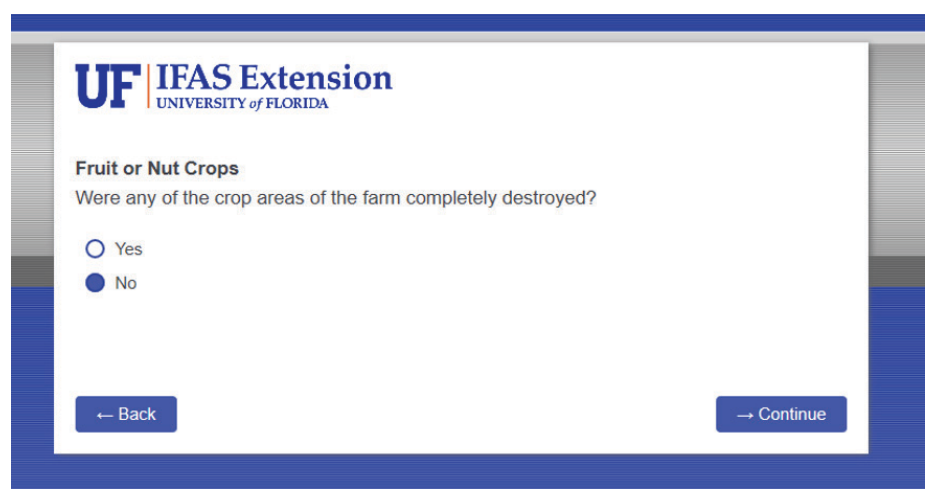

Figure 11. Identifying whether any of the crop areas of the farm were completely destroyed.

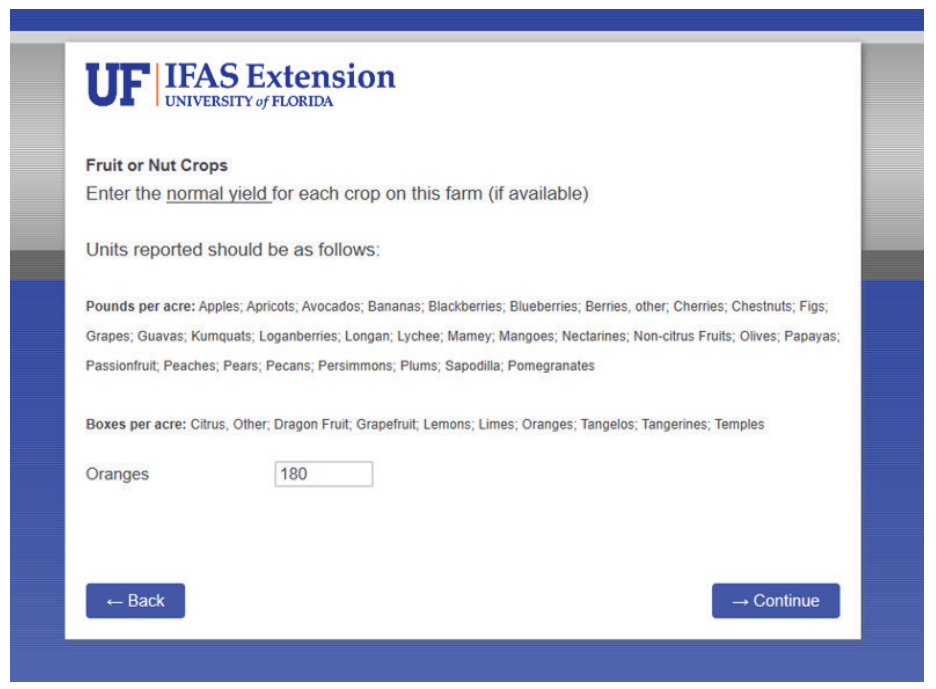

Figure 12. Entering normal yield of the crop.

The respondent will then be prompted to enter information related to physical damage caused by the disaster to any fixed assets on the operation. For this example, we will assume that there was only the observed damage to the perennial plants (orange trees) and one farm building on the property. The agent will select the check boxes for Other farm buildings and Perennial plants (e.g. fruit/nut orchards, vineyards) and press Continue, as shown in Figure 13.

The agent then moves on to screens that prompt them for information on the number of other farm buildings and the number and type of perennial plants destroyed by the disaster. The agent would enter the number of other farm buildings and orange trees destroyed in the hurricane and press Continue, as shown in Figures 14 and 15. Had any of the other fixed asset categories been chosen, the agent would be prompted to enter the number of buildings, equipment, fences, conservation structures, or other that were damaged. At this point, the survey does not solicit information on the value or amount of the asset in terms of building area, fence length, etc. However, this information might be incorporated into later versions of the survey. 


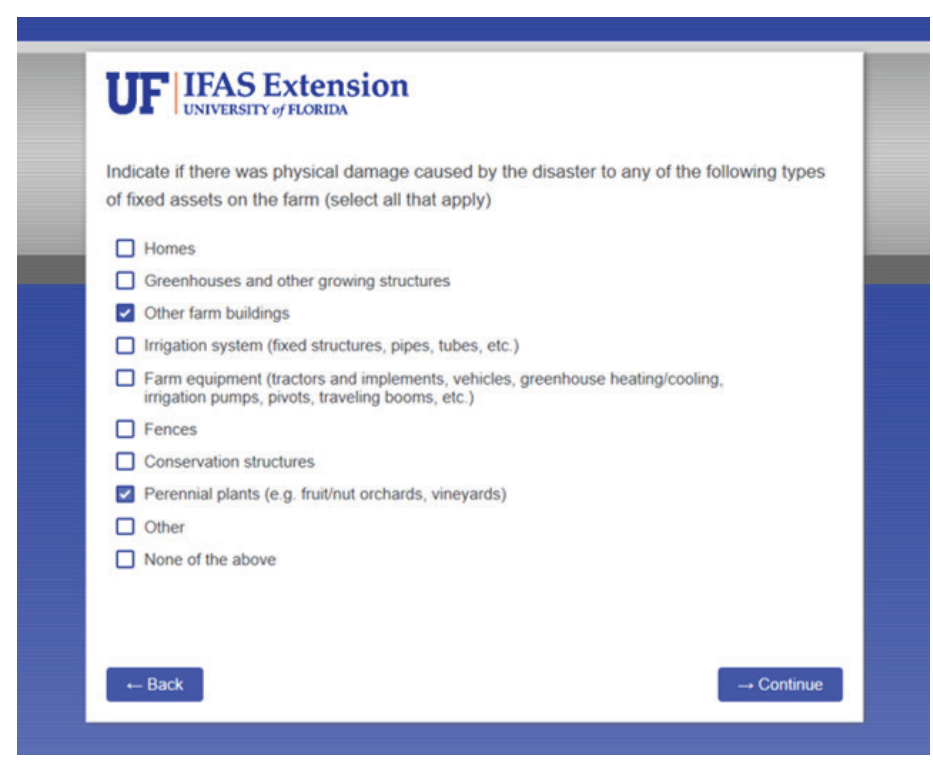

Figure 13. Selecting the categories of fixed assets damaged in the disaster.

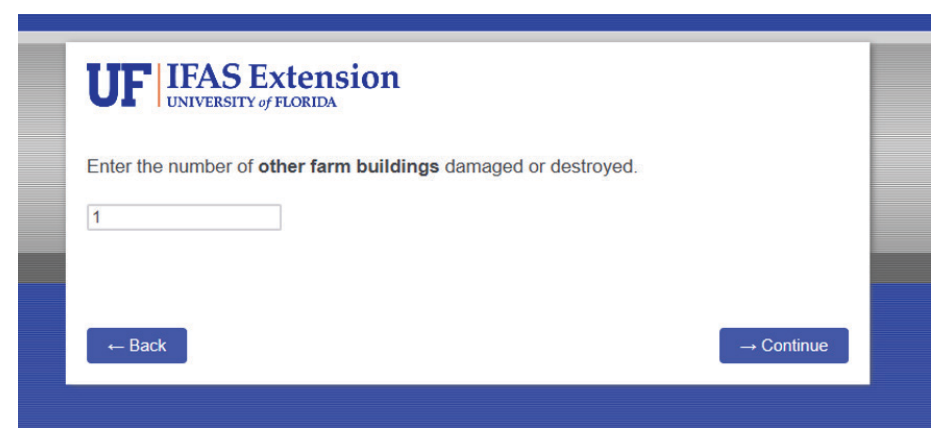

Figure 14. Entering information on other farm buildings damaged or destroyed.

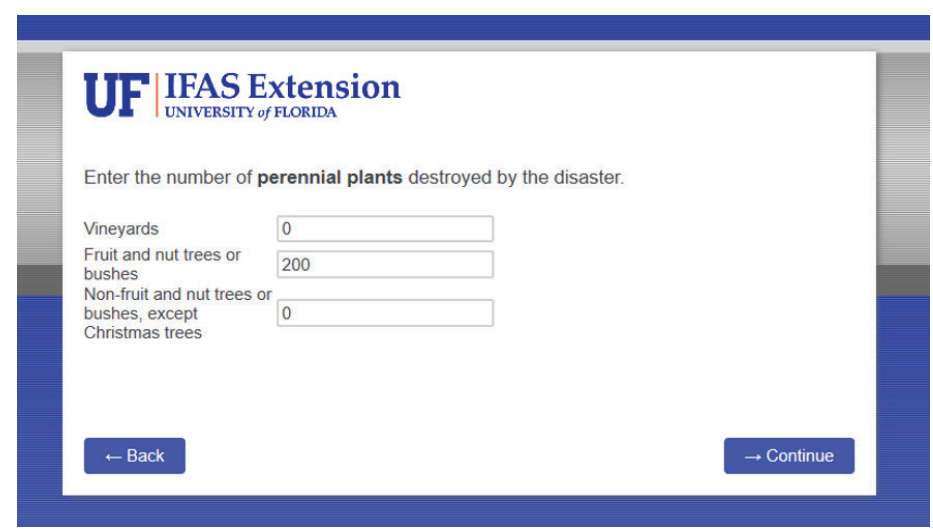

Figure 15. Entering information on perennial plants damaged.

Finally, the agent will have the option to provide any general comments about the disaster damages observed at the location that might be relevant to their reporting effort and to upload relevant photos. The agent is not required to enter information for these questions but, if applicable, would enter any information they deemed relevant and press Continue. Figures 16 and 17 display the screens in which this information is entered.

\section{UF| IFAS Extension}

Provide any general comments about disaster damages observed at this location

Figure 16. Entering general comments about the observed disaster damage.

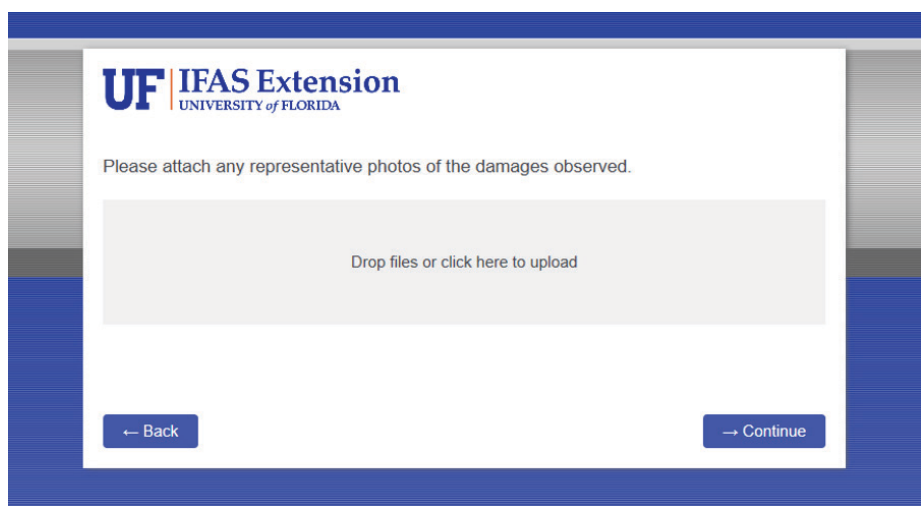

Figure 17. Uploading photos of the observed disaster damage.

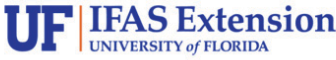

You have now completed the survey. Please feel free to look back at your responses to check for accuracy using the back arrow button. Thank you for your participation.

Figure 18. Survey completion notice and prompt to check for accuracy.

After pressing Continue, the agent will see a series of messages thanking them for their participation. The first message informs them that they have now completed the survey and that, if they choose, they can look back at their responses to check for accuracy using the back-arrow button, as shown in Figure 18. Once the Continue button is pressed on this screen, the survey responses are recorded and cannot be changed. Once the agent is satisfied with their responses, they press Continue and see the final thank you message displayed in Figure 19. 


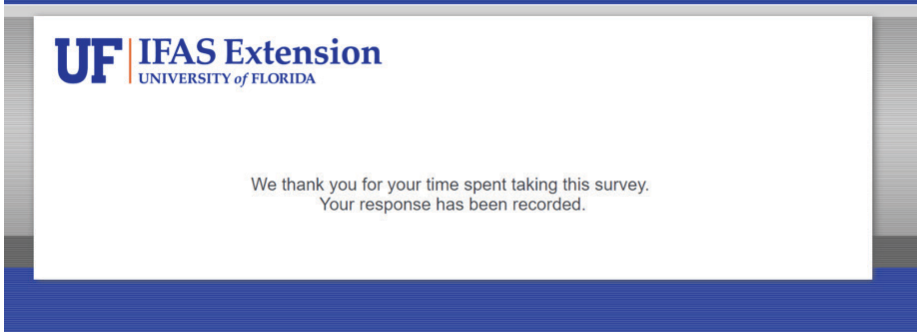

Figure 19. Final survey completion message and thank you.

\section{End Notes}

${ }^{1}$ The online survey instrument automatically collects the geo-coordinates of the computer or mobile device used.

\section{Appendix B: Paper Version of Post- Disaster Survey of Agricultural Damages and Losses}

This survey instrument was created to assist UF/IFAS Extension agents and USDA Farm Service Agency personnel to collect information on the impacts of natural disasters on the agriculture sector in Florida. This paper version of the survey is to be used when the online or offline Qualtrics survey is unavailable. The survey is to be completed for each farm or ranch operation visited or owner/manager interviewed.

Your name will be recorded for each survey record completed. All information will be kept strictly confidential. Only the principal investigators will have access to the detailed information collected in this survey. The results will be compiled and reported as county averages. You may choose whether to participate in the survey, and you may withdraw at any time. There is no personal compensation provided for participation.

If you have any questions about this project, contact the investigator: Christa D. Court, UF/IFAS Food \& Resource Economics Department, Email ccourt@ufl.edu, Telephone 352-294-7675.

By filling out this survey, your consent to participate is presumed. If you have any questions about your rights as a study participant, contact the University of Florida Institutional Review Board: irb2@ufl.edu, or 352-392-0433.

Thank you for your cooperation. 
Date:

Observer first and last name:

Name of farm or owner:

Did you observe losses/damages being reported first hand? (circle) Yes / No

Did you consult with a farm owner/manager or employee regarding the losses/damages being reported? (circle) Yes / No Select the Florida county or counties in which the farm is located (check all that apply)

\begin{tabular}{|l|l|l|l|}
\hline & Alachua & Hardee & Okeechobee \\
\hline & Baker & Hendry & Orange \\
\hline & Bay & Hernando & Osceola \\
\hline & Bradford & Highlands & Palm Beach \\
\hline & Brevard & Hillsborough & Pasco \\
\hline & Broward & Holmes & Pinellas \\
\hline & Calhoun & Indian River & Polk \\
\hline & Charlotte & Jackson & Putnam \\
\hline & Citrus & Jefferson & St. Johns \\
\hline & Clay & Lafayette & St. Lucie \\
\hline & Collier & Lake & Santa Rosa \\
\hline & Columbia & Lee & Sarasota \\
\hline & DeSoto & Leon & Seminole \\
\hline & Dixie & Levy & Sumter \\
\hline & Duval & Liberty & Suwannee \\
\hline & Escambia & Madison & Taylor \\
\hline & Flagler & Manatee & Union \\
\hline Franklin & Marion & Volusia \\
\hline & Gadsden & Martin & Wakulla \\
\hline Gilchrist & Miami-Dade & Walton \\
\hline Glades & Monroe & Washington \\
\hline Gulf & Nassau & \\
\hline Hamilton & Okaloosa & \\
\hline & & & \\
\hline
\end{tabular}

Disaster Type-choose the disaster type that best fits the event

\begin{tabular}{|l|l|l|l|}
\hline & Hurricane/Tropical Storm & Excess Rain & Freeze \\
\hline Severe Weather/Storm & Flood & Excess heat \\
\hline Tornado & Drought & Wildfire \\
\hline Wind & Hail & Other \\
\hline If Other, please specify: & & \\
\hline
\end{tabular}


In the following tables, for each crop, livestock, animal product, or type of infrastructure affected by the disaster, provide information on farm area or number of units, percentage damaged, percentage completely destroyed, percentage of production lost, and normal yield on the farm (if available).

\section{Units for reporting normal yield on farm:}

Table 4. Fruit crops.

\begin{tabular}{|c|c|c|c|c|c|}
\hline Crop & $\begin{array}{l}\text { Total farm area in } \\
\text { crop (acres) }\end{array}$ & $\begin{array}{c}\text { Percentage area } \\
\text { damaged }\end{array}$ & $\begin{array}{c}\text { Percentage } \\
\text { area completely } \\
\text { destroyed (100\% } \\
\text { loss) }\end{array}$ & $\begin{array}{c}\text { Production loss } \\
(\%)\end{array}$ & $\begin{array}{c}\text { Normal yield on this } \\
\text { farm } \\
\text { (see units below) }\end{array}$ \\
\hline \multicolumn{6}{|l|}{ Apples } \\
\hline \multicolumn{6}{|l|}{ Apricots } \\
\hline \multicolumn{6}{|l|}{ Avocados } \\
\hline \multicolumn{6}{|l|}{ Bananas } \\
\hline \multicolumn{6}{|l|}{ Blackberries } \\
\hline \multicolumn{6}{|l|}{ Blueberries } \\
\hline \multicolumn{6}{|l|}{ Berries, Other } \\
\hline \multicolumn{6}{|l|}{ Cherries } \\
\hline \multicolumn{6}{|l|}{ Chestnuts } \\
\hline \multicolumn{6}{|l|}{ Citrus, Other } \\
\hline \multicolumn{6}{|l|}{ Figs } \\
\hline \multicolumn{6}{|l|}{ Grapes } \\
\hline \multicolumn{6}{|l|}{ Guavas } \\
\hline \multicolumn{6}{|l|}{ Kumquats } \\
\hline \multicolumn{6}{|l|}{ Lemons } \\
\hline \multicolumn{6}{|l|}{ Limes } \\
\hline \multicolumn{6}{|l|}{ Loganberries } \\
\hline \multicolumn{6}{|l|}{ Mangoes } \\
\hline \multicolumn{6}{|l|}{ Nectarines } \\
\hline \multicolumn{6}{|l|}{ Non-citrus Fruits, Other } \\
\hline \multicolumn{6}{|l|}{ Olives } \\
\hline \multicolumn{6}{|l|}{ Oranges } \\
\hline \multicolumn{6}{|l|}{ Papayas } \\
\hline \multicolumn{6}{|l|}{ Passion Fruit } \\
\hline \multicolumn{6}{|l|}{ Peaches } \\
\hline \multicolumn{6}{|l|}{ Pears } \\
\hline \multicolumn{6}{|l|}{ Pecans } \\
\hline \multicolumn{6}{|l|}{ Persimmons } \\
\hline Plums \& Prunes & & & & & \\
\hline Pomegranates & & & & & \\
\hline Strawberries & & & & & \\
\hline Tangelos & & & & & \\
\hline Tangerines & & & & & \\
\hline Temples & & & & & \\
\hline Tree Nuts, Other & & & & & \\
\hline $\begin{array}{l}\text { Pounds per acre: App } \\
\text { Kumquats; Loganberri } \\
\text { Persimmons; Plums; } \\
\text { Boxes per acre: Citrus }\end{array}$ & $\begin{array}{l}\text {; Avocados; Bananas; } \\
\text {-ychee; Mamey; Man } \\
\text { hegranates } \\
\text { on Fruit; Grapefruit; }\end{array}$ & $\begin{array}{l}\text { lackberries; Bluebe } \\
\text { ses; Nectarines; Nor } \\
\text { emons; Limes; Oran }\end{array}$ & $\begin{array}{l}\text { ies; Berries, other; } \mathrm{Cl} \\
\text { citrus Fruits; Olives; } \\
\text { es; Tangelos; Tangeri }\end{array}$ & $\begin{array}{l}\text { rries; Chestnuts; Fi } \\
\text { payas; Passionfrui } \\
\text { es; Temples }\end{array}$ & $\begin{array}{l}\text {;; Grapes; Guavas; } \\
\text { Peaches; Pears; Pecans; }\end{array}$ \\
\hline
\end{tabular}


Table 5. Vegetable crops.

\begin{tabular}{|c|c|c|c|c|c|}
\hline Crop & $\begin{array}{l}\text { Total farm area } \\
\text { in crop (acres) }\end{array}$ & $\begin{array}{l}\text { Percentage area } \\
\text { damaged }\end{array}$ & $\begin{array}{c}\text { Percentage } \\
\text { area completely } \\
\text { destroyed (100\% } \\
\text { loss) }\end{array}$ & $\begin{array}{l}\text { Production loss } \\
(\%)\end{array}$ & $\begin{array}{l}\text { Normal yield on this } \\
\text { farm (pounds) }\end{array}$ \\
\hline \multicolumn{6}{|l|}{ Asparagus } \\
\hline \multicolumn{6}{|l|}{ Beans } \\
\hline \multicolumn{6}{|l|}{ Beets } \\
\hline \multicolumn{6}{|l|}{ Broccoli } \\
\hline \multicolumn{6}{|l|}{ Cabbage } \\
\hline \multicolumn{6}{|l|}{ Carrots } \\
\hline \multicolumn{6}{|l|}{ Cauliflower } \\
\hline \multicolumn{6}{|l|}{ Celery } \\
\hline \multicolumn{6}{|l|}{ Cantaloupe } \\
\hline \multicolumn{6}{|l|}{ Cucumbers } \\
\hline \multicolumn{6}{|l|}{ Daikon } \\
\hline \multicolumn{6}{|l|}{ Eggplant } \\
\hline \multicolumn{6}{|l|}{ Escarole \& Endive } \\
\hline \multicolumn{6}{|l|}{ Garlic } \\
\hline \multicolumn{6}{|l|}{ Greens } \\
\hline \multicolumn{6}{|l|}{ Herbs } \\
\hline \multicolumn{6}{|l|}{ Lettuce } \\
\hline \multicolumn{6}{|l|}{ Melons, Other } \\
\hline \multicolumn{6}{|l|}{ Onions } \\
\hline \multicolumn{6}{|l|}{ Parsley } \\
\hline \multicolumn{6}{|l|}{ Peas } \\
\hline \multicolumn{6}{|l|}{ Peppers } \\
\hline \multicolumn{6}{|l|}{ Potatoes, white } \\
\hline \multicolumn{6}{|l|}{ Pumpkins } \\
\hline \multicolumn{6}{|l|}{ Radishes } \\
\hline \multicolumn{6}{|l|}{ Spinach } \\
\hline \multicolumn{6}{|l|}{ Squash } \\
\hline \multicolumn{6}{|l|}{ Sweet Corn } \\
\hline \multicolumn{6}{|l|}{ Sweet Potatoes } \\
\hline Tomatoes & & & & & \\
\hline Vegetables, Other & & & & & \\
\hline Watercress & & & & & \\
\hline Watermelon & & & & & \\
\hline
\end{tabular}


Table 6. Field crops.

\begin{tabular}{|c|c|c|c|c|c|}
\hline Crop & $\begin{array}{l}\text { Total farm area in } \\
\text { crop (acres) }\end{array}$ & $\begin{array}{l}\text { Percentage area } \\
\text { damaged }\end{array}$ & $\begin{array}{c}\text { Percentage } \\
\text { area completely } \\
\text { destroyed ( } 100 \% \\
\text { loss) }\end{array}$ & $\begin{array}{c}\text { Production loss } \\
(\%)\end{array}$ & $\begin{array}{l}\text { Normal yield on this } \\
\text { farm } \\
\text { (see units below) }\end{array}$ \\
\hline \multicolumn{6}{|l|}{ Canola } \\
\hline \multicolumn{6}{|l|}{ Corn } \\
\hline \multicolumn{6}{|l|}{ Cotton } \\
\hline \multicolumn{6}{|l|}{ Grasses \& Legumes } \\
\hline \multicolumn{6}{|l|}{ Hay, Haylage, Silage } \\
\hline \multicolumn{6}{|l|}{ Millet } \\
\hline \multicolumn{6}{|l|}{ Oats } \\
\hline \multicolumn{6}{|l|}{ Peanut } \\
\hline \multicolumn{6}{|l|}{ Peas } \\
\hline \multicolumn{6}{|l|}{ Popcorn } \\
\hline \multicolumn{6}{|l|}{ Rice } \\
\hline \multicolumn{6}{|l|}{ Rye } \\
\hline \multicolumn{6}{|l|}{ Sesame } \\
\hline \multicolumn{6}{|l|}{ Short Term Woody Crops } \\
\hline \multicolumn{6}{|l|}{ Sod } \\
\hline \multicolumn{6}{|l|}{ Sorghum (grain) } \\
\hline \multicolumn{6}{|l|}{ Soybeans } \\
\hline \multicolumn{6}{|l|}{ Sugarcane } \\
\hline \multicolumn{6}{|l|}{ Sunflower } \\
\hline \multicolumn{6}{|l|}{ Tobacco } \\
\hline \multicolumn{6}{|l|}{ Triticale } \\
\hline \multicolumn{6}{|l|}{ Wheat } \\
\hline Other Field Crops & & & & & \\
\hline
\end{tabular}

Bushels per acre: Canola; Corn (grain); Millet; Oats; Popcorn; Rice; Rye; Sorghum (grain); Soybeans; Triticale; Wheat

Tons per acre: Hay, Haylage, and Silage; Short Term Woody Crops; Sod; Sugarcane

Pounds per acre: Cotton; Grasses \& Legumes; Peanut; Peas; Sesame; Sunflower; Tobacco; Other 
Table 7. Horticultural crops-greenhouse and nursery.

\begin{tabular}{|c|c|c|c|c|c|}
\hline Crop & $\begin{array}{c}\text { Total farm } \\
\text { area in crop } \\
\text { (square feet) }\end{array}$ & $\begin{array}{c}\text { Percentage area } \\
\text { damaged }\end{array}$ & $\begin{array}{c}\text { Percentage } \\
\text { area completely } \\
\text { destroyed }(100 \% \\
\text { loss) }\end{array}$ & $\begin{array}{c}\text { Production loss } \\
(\%)\end{array}$ & $\begin{array}{c}\text { Normal yield } \\
\text { on this farm } \\
\text { (plants) }\end{array}$ \\
\hline \multicolumn{6}{|l|}{ Aquatic Plants } \\
\hline \multicolumn{6}{|l|}{ Bulbs, Corms, Rhizomes \& Tubers } \\
\hline \multicolumn{6}{|l|}{ Christmas Trees } \\
\hline \multicolumn{6}{|l|}{ Cut Flowers \& Cultivated Greens } \\
\hline \multicolumn{6}{|l|}{ Floriculture, Other } \\
\hline \multicolumn{6}{|l|}{ Flower or Vegetable Seeds } \\
\hline \multicolumn{6}{|l|}{ Flowering Plants, Potted } \\
\hline \multicolumn{6}{|l|}{ Tropical Foliage Plants } \\
\hline \multicolumn{6}{|l|}{ Mushrooms } \\
\hline \multicolumn{6}{|l|}{ Propagative Material } \\
\hline \multicolumn{6}{|l|}{ Transplants } \\
\hline Woody Ornamental Trees and Shrubs & & & & & \\
\hline
\end{tabular}

Table 8. Livestock and aquaculture.

\begin{tabular}{|c|c|c|}
\hline Animal type & Number on farm & Number lost \\
\hline \multicolumn{3}{|l|}{ Alpacas } \\
\hline \multicolumn{3}{|l|}{ Bison } \\
\hline \multicolumn{3}{|l|}{ Beef cattle 400 lbs. or less } \\
\hline \multicolumn{3}{|l|}{ Beef cattle greater than 400 lbs. } \\
\hline \multicolumn{3}{|l|}{ Dairy cattle 400 lbs. or less } \\
\hline \multicolumn{3}{|l|}{ Dairy cattle greater than 400 lbs. } \\
\hline \multicolumn{3}{|l|}{ Chickens } \\
\hline \multicolumn{3}{|l|}{ Deer } \\
\hline \multicolumn{3}{|l|}{ Ducks } \\
\hline \multicolumn{3}{|l|}{ Elk } \\
\hline \multicolumn{3}{|l|}{ Emus } \\
\hline \multicolumn{3}{|l|}{ Equine (Horses, Donkeys) } \\
\hline \multicolumn{3}{|l|}{ Finfish } \\
\hline \multicolumn{3}{|l|}{ Goats } \\
\hline \multicolumn{3}{|l|}{ Guineafowl } \\
\hline \multicolumn{3}{|l|}{ Hogs } \\
\hline \multicolumn{3}{|l|}{ Honeybee Colonies } \\
\hline \multicolumn{3}{|l|}{ Ostriches } \\
\hline \multicolumn{3}{|l|}{ Pheasants } \\
\hline \multicolumn{3}{|l|}{ Pigeons \& Squab } \\
\hline \multicolumn{3}{|l|}{ Poultry, Other } \\
\hline \multicolumn{3}{|l|}{ Quail } \\
\hline \multicolumn{3}{|l|}{ Rabbits } \\
\hline \multicolumn{3}{|l|}{ Sheep } \\
\hline \multicolumn{3}{|l|}{ Shellfish } \\
\hline \multicolumn{3}{|l|}{ Specialty Animals, Other } \\
\hline Turkeys & & \\
\hline
\end{tabular}


Table 9. Animal products.

\begin{tabular}{|l|l|l|}
\hline \multicolumn{1}{|c|}{ Product } & Amount produced on farm last year & Number lost in disaster \\
\hline Eggs (number) & & \\
\hline Honey (pounds) & & \\
\hline Milk (hundredweight) & & \\
\hline
\end{tabular}

Table 10. Infrastructure.

\begin{tabular}{|l|l|l|}
\hline \multicolumn{1}{|c|}{ Asset type } & \multicolumn{1}{|c|}{ Quantity on farm } & Quantity destroyed \\
\hline Homes (number) & & \\
\hline Greenhouses and other growing structures (number) & & \\
\hline Other farm buildings (number) & & \\
\hline Irrigation system structures (number) & & \\
\hline $\begin{array}{l}\text { Farm equipment: tractors, implements, vehicles, } \\
\text { greenhouse heating/cooling (number) }\end{array}$ & & \\
\hline Fences (linear feet) & & \\
\hline Conservation structures: ponds, dams, culverts (number) & & \\
\hline Vineyards (number plants) & & \\
\hline Fruit/nut trees or bushes (number plants) & & \\
\hline $\begin{array}{l}\text { Non-fruit trees or bushes, except Christmas trees } \\
\text { (number plants) }\end{array}$ & \\
\hline $\begin{array}{l}\text { Aquaculture structures: ponds, tanks, equipment } \\
\text { (number) }\end{array}$ & & \\
\hline $\begin{array}{l}\text { Other structures (number) } \\
\text { Describe: }\end{array}$ & \\
\hline
\end{tabular}

Briefly describe any other types of damages or losses or general comments about disaster damages observed on this farm:

You have now completed the survey. Thank you for your participation. 